\title{
ANALISIS MODEL PEMBELAJARAN NHT DALAM MENINGKATAKAN KEMAMPUAN BERPIKIR KRITIS
}

\author{
Diratna Briliandika $^{1)}$, Deni Adi Putra ${ }^{2)}$, Kunti Dian Ayu Afiani ${ }^{3)}$ \\ 1,2,3) Universitas Muhammadiyah Surabaya \\ diratna.briliandika-2016@fkip.um-surabaya.ac.id
}

\begin{tabular}{ll}
\hline & \multicolumn{1}{c}{ Abstrak } \\
\hline Kata Kunci: & Penelitian ini bertujuan untuk menganalisis model pembelajaran NHT dalam \\
Numbered & meningkatkan kemampuan berpikir kritis siswa. Numberred Head Togather \\
Heads & (NHT) adalah model pembelajaran kepala bernomor yang anggotanya dan \\
Togather & berkelompok secara heterogen, kemudian secara acak guru memanggil nomor \\
(NHT), & dari siswa sehingga setiap siswa mempunyai kewajiban sendiri-sendiri dan \\
Kemampuan & mengecek pemahaman siswa terhadap materi pembelajaran. Penelitian ini \\
berpikir kritis & adalah penelitian kualitatif yang bersifat studi kepustakaan (library research), \\
& penelitian dilakukan dengan cara mengumpulkan data dengan menggunakan \\
& buku, serta berbagai jurnal yang berkaitan dengan variabel penelitian yang \\
& dibutuhkan. Dari hasil penelusuran diperoleh 9 artikel dari jurnal dan 1 dari \\
& repository. Berdasarkan hasil analisis ternyata model pembelajaran Numbered \\
& Heads Togather (NHT) mampu meningkatkan kemampuan berpikir siswa mulai \\
& dari yang dari rata-rata yang 51,6\% dengan nilai presentase terendah adalah $6 \%$ \\
dan tertinggi mencapai 133\%. Selain meningkatkan berpikir kritis siswa model & Numbered Head together juga dapat membuat siswa menjadi lebih aktif saling \\
& berdiskusi untuk memcahkan permasalahan dan memahami materi
\end{tabular}

\begin{tabular}{l}
\hline Keywords: \\
Numbered Heads \\
Together (NHT), \\
Critical Thinking \\
Skill
\end{tabular}

\section{Abstract:}

This study aimed to analyze the NHT learning model for improving students' critical thinking skills. Numbered Head Together (NHT) is a numbered head learning model whose members and groups are heterogeneous; then, the teacher randomly calls the number from the student so that each student has his obligation and checks the student's understanding of the learning material. This research was qualitative research with literary study research. The research was carried out by collecting data using books and various journals related to the required research variables. The search results obtained nine articles from journals and one from the repository. Based on the analysis results, it turns out that the Numbered Heads Together (NHT) learning model can improve students' thinking skills, starting from an average of $51.6 \%$ with the lowest percentage value being $6 \%$ and the highest reaching $133 \%$. In addition to improving students' critical thinking, the Numbered Head together model might also make students more active in discussing each other to solve problems and understand the material

\section{Pendahuluan}

Pendidikan memegang peranan penting dalam rangka memperbaiki kualitas Sumber Daya Manusia (SDM) suatu bangsa. Hal tersebut merupakan salah satu tujuan bangsa Indonesia yang tertera dalam Pembukaan Undang-

Undang Dasar 1945 alinea keempat

"Mencerdaskan kehidupan bangsa".

Pada Undang-undang Sistem Pendidikan

Nasional Undang-Undang Republik

Indonesia No. 20 Tahun 2003 BAB 1 
Pasal 1 menyatakan bahwa "Pendidikan adalah usaha sadar dan terencana untuk mewujudkan susasana belajar dan proses pembelajaran siswa secara aktif mengembangkan potensi dirinya untuk memiliki kekuatan spiritual keagamaan pengendalian diri, kepribadian, kecerdasan, akhlak mulia, serta keterampilan yang diperlukan dirinya, masyarakat, bangsa dan negara". Berdasarkan undang-undang tersebut, pendidikan diharapkan dapat mengembangkan potensi siswa agar menjadi manusia yang cerdas, beriman dan bertakwa kepada Tuhan Yang Maha Esa, mandiri, serta berkakhlak mulia.

$$
\text { Perkembangan pembelajaran }
$$

pada abad ke 21 menuntut pola pikir siswa menjadi HOTS (high order thinking skill) dalam memajukan pendidikan di Indonesia. Pada saat ini, Pendidikan berada di masa berbasis pengetahuan (knowledge age). Untuk menghadapi tantangan pada abad 21 pemerintah merancang pembelajaran yang menerapkan kemampuan 4C (critical thingking, communication, collaboration, creativity). Salah satu kemampuan 4C yaitu critical Thingking (berpikir kritis). Berpikir kritis adalah sebuah proses dalam menggunakan keterampilan berpikir secara efektif untuk membantu seseorang membuat sesuatu,

mengevaluasi,

dan mengaplikasikan ketetapan sesuai dengan apa yang diyakini atau dilaksanakan (Siswono, 2018:8). Berpikir kritis merupakan proses yang melibatkan integrasi pengalaman pribadi, pelatihan, dan skill (kemampuan/ kemahiran) disertai dengan alasan dalam mengambil keputusan untuk menjelaskan kebenaran sebuah informasi (Lismaya, 2019:9). Menurut Santrock (dalam Hidayah \& Anisa, 2019:168) kemampuan berpikir kritis adalah pemikiran refleksi produktif yang melibatkan hasil dan bukti. Menurut Schafersman (dalam Putra, 2018:57) berpikir kritis merupakan cara berpikir yang tepat dalam pencarian pengetahuan yang relevan sesuai degan bukti yang ada. Seseorang dapat dikatakan berpikir kritis apabila mampu mengajukan pertanyaan yang cocok, mengumpulkan informasi yang relevan, bertindak secara efisien dan kreatif, dapat mengemukakan argumen yang logis berdasarkan informasi, dan dapat mengambil simpulan yang dapat dipercaya.

\section{Berpikir kritis adalah} kemampuan yang dimiliki seseorang secara reflektif yang melibatkan pengalaman pribadi, pelatihan dan skill yang melibatkan hasil dan bukti. 
Meningkatkan kemampuan bepikir kritis dapat dilakukan dengan guru menggunakan model pembelajaran. Salah satu model pembelajaran yang dapat membuat keaktifan siswa serta meningkatkan kemampuan berpikir kritis adalah model Numberd Head Together (NHT). Menurut (Achmad, 2018:8) model pembelajaran Numbered Head Together dengan problem solving merupakan model pembelajaran yang dapat meningkatkan kemampuan berpikir kritis siswa, hal ini ditunjang dengan peningkatan hasil belajar kognitif,psikomotor dan afektif siswa.

Menurut (Shoimin, 2014:108) Numberred Head Togather merupakan suatu model pembalajaran berkelompok yang setiap anggotanya bertanggung jawab atas tugas kelompoknya, sehingga tidak ada pemisah antara siswa satu dan siswa yang lain dalam satu kelompok untuk saling mem beri dan menerima anatara satu dengan yang lainnya. Menurut (Machfud, 2018:111) merupakan salah satu tipe pembelajaran kooperatif yang menekankan pada struktur-struktur khusus dirancang untuk mempengaruhi pola-pola interaksi siswa dalam memliki tujuan meningkatkan penguasaan isi akademik.

Berdasarkan pendapat ahli di atas Numberred Head Togather (NHT) adalah model pembelajaran kepala bernomor yang anggotanya dan berkelompok secara heterogen, kemudian secara acak guru memanggil nomor dari siswa sehingga setiap siswa mempunyai kewajiban sendiri-sendiri dan mengecek pemahaman siswa terhadap materi pembelajaran.

Menurut (Machfud, 2018:113) model pembelajaran NHT mempunyai kelebihan dan kekurangan sebagai berikut.

1. Kelebihan
a. memberikan motivasi,
b. menambah rasa percaya diri,
c. siswa menjadi lebih aktif

2. Kelemahan

a. Memerlukan waktu yang agak panjang,

b. Membuat siswa panik atau grogi, dan

c. Memerlukan konsentrasi dalam mengelola kelas.

Dari pendapat diatas peneliti menyimpulkan bahwa model NHT mempunyai kelebihan dan kekurangan, namun untuk mengatasi kekurangan tersebut dapat diatasi dengan persiapan yang baik dari guru sebelum pembelajaran berlangsung, guru dapat memberikan pre-test untuk mengetahui kemampuan siswa, untuk mengetahui pemahaman siswa terhadap materi 
pembelajaran guru melakukan evaluasi. Dengan refleksi untuk perbaikan pada pertemuan berikutnya dalam mengontrol kekurangan yang ada pada model pembelajaran model NHT.

Berdasarkan hasil pada pendahuluan di atas, Penelitian ini bertujuan untuk menganalisis model pembelajaran NHT dalam meningkatkan kemampuan berpikir kritis siswa.

\section{Metode Penelitian}

Penelitian yang digunakan adalah jenis penelitian kualitatif menggunakan dengan menggunakan metode studi kepustakaan (library research). Menurut Khatibah (dalam Sari \& Admendri, 2020:44) mengemukakan penelitian kepustakaan merupakan kegiatan yang dilakukan secara sistematis untuk mengumpulkan, mengolah, dan menyimpulkan data dengan menggunakan metode/teknik tertentu untuk mencari jawaban atas permasalahan yang dihadapi melalui penelitian kepustakaan. Studi kepustakaan berkaitan dengan kajian secara teori melalui referensi-referensi terkait dengan nilai, budaya, dan norma yang berkembang pada situasi sosial yang diteliti. (Sugiyono, 2018:291)

Penelitian keperpustakaan dalam penelitian ini hanya menganalisis dari beberapa artikel dengan menggunakan metode perbandingan yang bertujuan mengetahui selisih sebelum dan sesudah pembelajaran. Data tersebut dihitung untuk mengetahui persentase kenaikan kemampuan berpikir kritis siswa, dengan menggunakan rumus:

1. peningkatan sudah dalam bentuk persen (\%) adalah data sesudah pembelajaran dikurangi dikurangi data sebelum pembelajaran, dan

2. peningkatan masih dengan nilai rata-rata adalah data sesudah pembelajaran dikurangi data sebelum pembelajaran dibagi dengan data sebelum diberikan pembelajaran dan setelah itu dikali seratus persen (\%). (Kristin, 2016:95)

\section{Hasil dan Pembahasan}

Hasil penelitian diperoleh sepuluh artikel yang terkait dengan model pembelajaran NHT (Numberred Head Togather) dalam meningkatkan kemampuan berpikir kritis siswa antara lain sebagai berikut.

1. Novitasari : Upaya Meningkatkan Kemampuan Berpikir Kritis Siswa Melalui Model Pembelajaran Kooperatif Tipe Numbered Heads Togather (NHT) pada Siswa Kelas VIID SMP Negeri 11 Yogyakarta. 
2. Wati: Effect Size Pembelajaran Kooperatif Tipe Numbered Heads Togather (NHT) Terhadap Kemampuan Berpikir Kritis Siswa pada Pelajaran Fisika.

3. Febrianti: Implementasi Model Pembelajaran Kooperatif Tipe Numbered Heads Together (NHT) Dalam Meningkatkan Kemampuan Berpikir Kritis Siswa Pada Pembelajaran IPS.

4. Bano: Penerapan Model Numbered Heads Togather dan Group Investigation untuk/Meningkatkan Kemampuan Berpikir Kritis Siswa.

5. Amry: Upaya Meningkatkan Kemampuan Berpikir Kritis Siswa Kelas X Melalui Pembelajaran Kooperatif Tipe Numbered Heads Together.

6. Achmad: Peningkatan Kemampuan Berpikir Kritis Siswa Menggunakan Model Pembelajaran Kooperatif Tipe Numbered Heads Togather Berbasis Problem Solving.

7. Andriyani: Penerapan Model Numbered Heads Togather (NHT) Dilengkapi Catatan Terbimbing untuk Meningkatkan Kemampuan Berpikir Kritis dan Prestasi Belajar pada Materi Hasil Kali Kelarutan
Kelas XI SMA Negeri 2 Sukoharjo Tahun Pelajaran 2013/2014.

8. Khasanah:

Peningkatan

Kemampuan Berpikir Kritis dan Prestasi Belajar Matematika Melalui Model Pembelajaran Kooperatif Tipe NHT.

9. Permana: Penerapan Metode Pembelajaran Kooperatif Numberred Heads Togather untuk meningkatkan hasil belajar dan berpikir Kritis Siwa pada Mata Pelajaran IPS SD

10. Wibawa: Penerapan Model Pembelajaran Numbered Heads Togather (NHT) untuk Meningkatkan Kemampuan Berpikir Kritis Pkn Siswa Kelas VIII B8. Jurnal diatas telah diambil berdasarkan variabel yang telah ditentukan. jurnal tersebut diperoleh dari internet dalam penelitian ini maka data yang telah diperoleh akan dianalisis secara deskriptif kualitatif dan kuantitatif. 
Tabel 1. Hasil Analisis Model Pembelajaran NHT

\begin{tabular}{|c|c|c|c|c|c|c|c|}
\hline \multirow[t]{2}{*}{ No. } & \multirow[t]{2}{*}{ Judul } & \multirow[t]{2}{*}{ Peneliti } & \multirow[t]{2}{*}{ Tahun } & \multicolumn{4}{|c|}{ Peningkatan Kemampuan Berpikir Kritis } \\
\hline & & & & Sebelum & Sesudah & Selisih & $\%$ \\
\hline & * Data dalam Be & tuk Nilai $\mathbf{R}$ & a-rata & & & & \\
\hline 1. & $\begin{array}{l}\text { Upaya } \\
\text { Meningkatkan } \\
\text { Kemampuan } \\
\text { Berpikir Kritis } \\
\text { Siswa } \\
\text { Melalui Model } \\
\text { Pembelajaran } \\
\text { Kooperatif Tipe } \\
\text { Numbered } \\
\text { Heads Togather } \\
\text { (NHT) } \\
\text { pada Siswa } \\
\text { Kelas VIID } \\
\text { SMP Negeri } 11 \\
\text { Yogyakarta }\end{array}$ & $\begin{array}{c}\text { Alfi } \\
\text { Novitasari }\end{array}$ & 2015 & 55,30 & 79,12 & 23,82 & 43 \\
\hline 2. & $\begin{array}{l}\text { Effect Size } \\
\text { Pembelajaran } \\
\text { Kooperatif Tipe } \\
\text { Numbered } \\
\text { Heads Togather } \\
\text { (NHT) } \\
\text { Terhadap } \\
\text { Kemampuan } \\
\text { Berpikir Kritis } \\
\text { Siswa pada } \\
\text { Pelajaran Fisika }\end{array}$ & $\begin{array}{l}\text { Widya } \\
\text { Wati, Rini } \\
\text { Fatimah }\end{array}$ & 2016 & 36,97 & 80,35 & 43.38 & 117 \\
\hline 3. & $\begin{array}{l}\text { Implementasi } \\
\text { Model } \\
\text { Pembelajaran } \\
\text { Kooperatif Tipe } \\
\text { Numbered } \\
\text { Heads Together } \\
\text { (NHT) Dalam } \\
\text { Meningkatkan } \\
\text { Kemampuan } \\
\text { Berpikir Kritis } \\
\text { Siswa Pada } \\
\text { Pembelajaran } \\
\text { IPS }\end{array}$ & $\begin{array}{l}\text { Fitri Ayu } \\
\text { Febrianti }\end{array}$ & & & & 36,7 & 91 \\
\hline 4. & $\begin{array}{l}\text { Penerapan } \\
\text { Model } \\
\text { Numbered } \\
\text { Heads Togather } \\
\text { dan Group } \\
\text { Investigation } \\
\text { untuk } \\
\text { Meningkatkan } \\
\text { Kemampuan } \\
\text { Berpikir Kritis } \\
\text { Siswa }\end{array}$ & $\begin{array}{c}\text { Natalia } \\
\text { Desiana } \\
\text { Naikteas } \\
\text { Bano, } \\
\text { Amiruddin } \\
\text { Supu, dan } \\
\text { Vinsensius } \\
\text { Lantik }\end{array}$ & 2019 & 30,28 & 70,57 & 40,29 & 133 \\
\hline
\end{tabular}




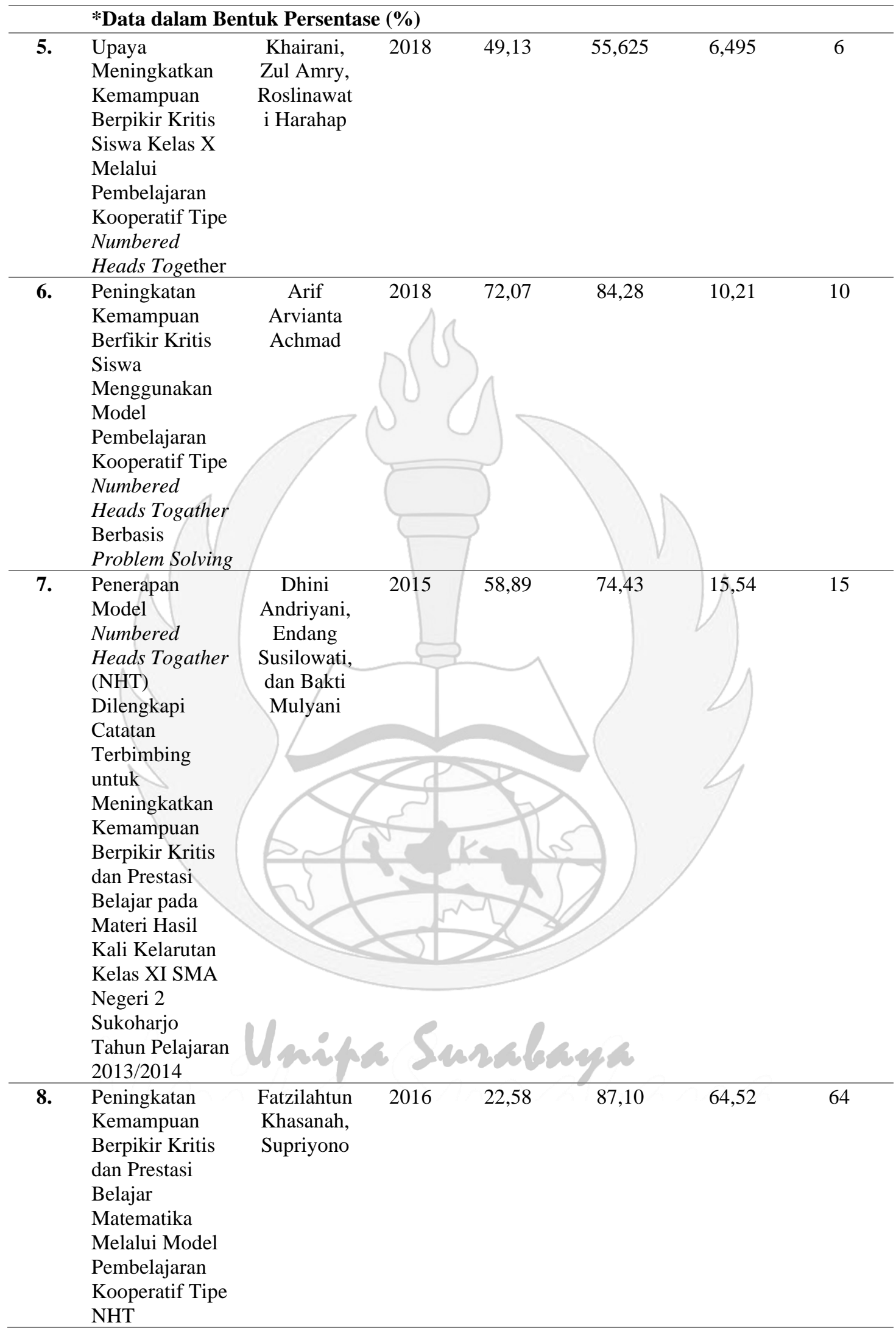




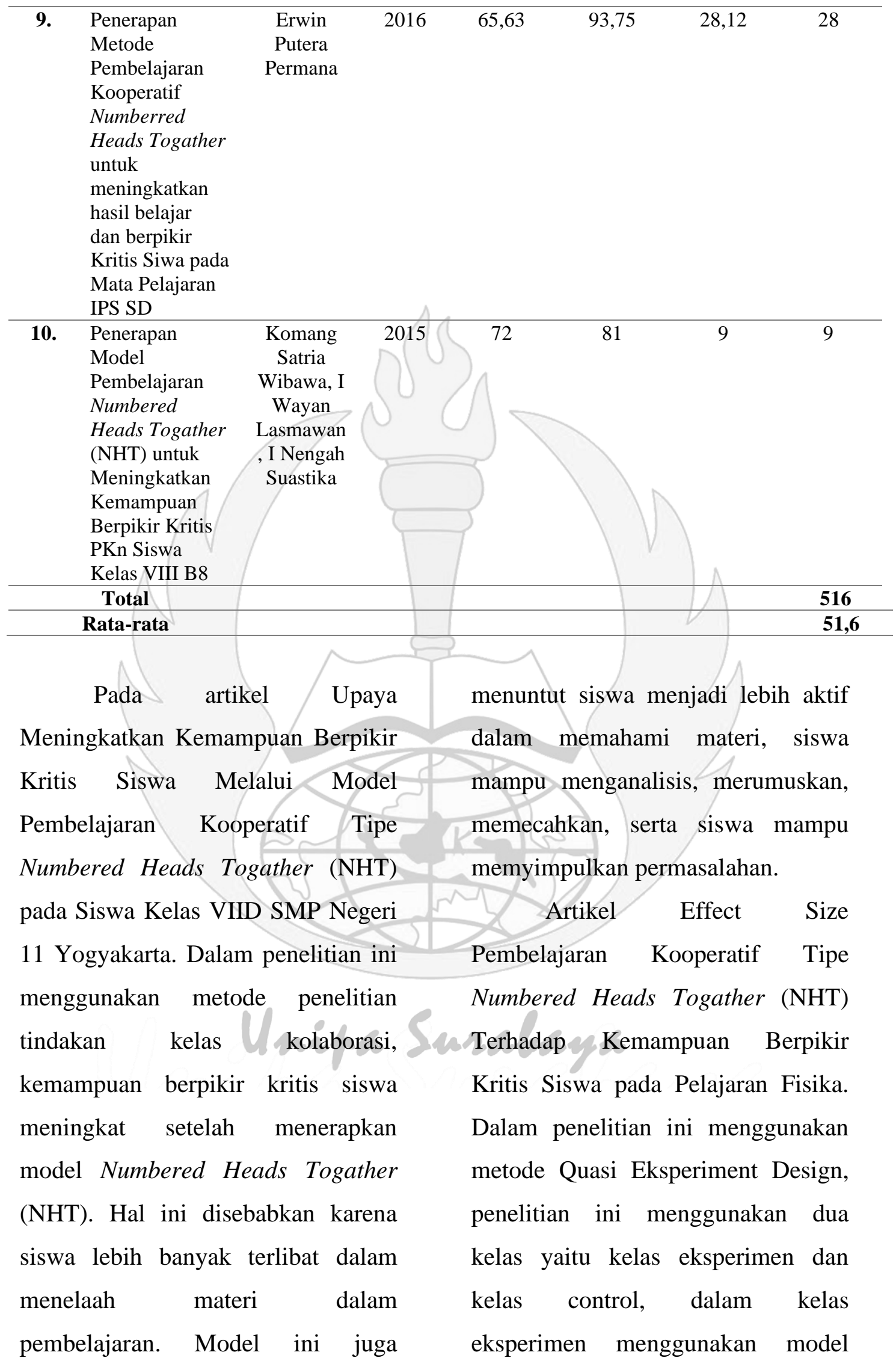


NHT, sedangkan kelas control menggunakan model konvensional. Saat diterapkan Model NHT siswa melakukan identifikasi masalah yang memberikan hipotesis, kemudian menganalisa masalah dan mendiskusikan masalah tersebut dalam kelompok sehingga siswa bisa memberikan evaluasi kritis terhadap permasalahan.

Artikel Implementasi Model Pembelajaran Kooperatif Tipe Numbered Heads Together (NHT) Dalam Meningkatkan Kemampuan Berpikir Kritis Siswa Pada Pembelajaran IPS. Dalam penelitian ini metode penelitian eksperimen, penelitian ini menggunakan dua kelas yaitu kelas eksperimen dan kelas control, dalam kelas eksperimen menggunakan model NHT, sedangkan kelas control menggunakan model konvensional berbasis gambar. Saat diterapkan Model NHT mayoritas siswa mulai menikmati alur pembelajaran dan terstimulus begitu baik. siswa dapat menyelesaikan masalah secara bersama kelompok dan menumbuhkan sikap mandiri saat nomornya dipanggil ke depan kelas.
Artikel Penerapan Model Numbered Heads Togather dan Group Investigation untuk Meningkatkan Kemampuan Berpikir Kritis Siswa. Dalam penelitian ini menngunakan metode penelitian Randomised-Control group pretestpostest. Penelitian ini menggunakan dua kelas yaitu kelas eksperimen A dan kelas eksperimen $\mathrm{B}$, dalam kelas eksperimen A menggunakan model NHT, sedangkan kelas eksperimen B menggunakan model Group Investigation. Dalam kelas eksperimen A siswa diberikan permasalahan oleh guru sehingga pikiran siswa terfokus dan terarah pada pertanyaan yang ada dan siswa memecahkan permasalahan denga berdiskusi kelompok atau melakukan praktikum sederhana untuk mencari solusi dari permasalahan yang diberikan.

Artikel Upaya Meningkatkan Kemampuan Berpikir Kritis Siswa Kelas X Melalui Pembelajaran Kooperatif Tipe Numbered Heads Together. Dalam penelitian ini menggunakan metode penelitian tindakan kelas (classroom action research), kemampuan berpikir kritis 
siswa meningkat setelah menerapkan pembelajaran ini. Penerapan pembelajaran ini juga dapat meningkatkan aktivitas siswa saat pembelajaran.

Artikel Peningkatan

Kemampuan Berfikir Kritis Siswa Menggunakan Model Pembelajaran Kooperatif Tipe Numbered Heads Togather Berbasis Problem Solving. Dalam penelitian ini menggunakan metode penelitian tindakan kelas, siswa melakukan penyelidikan dan melakukan diskusi bersama kelompok, setiap siswa bertanggung jawab atas permasalahan dalam setiap kelompok, siswa dapat mengkonstruksi sendiri pengetahuanya sebagai hasil kerjasama kelompok.

Artikel Penerapan Model Numbered Heads Togather (NHT) Dilengkapi Catatan Terbimbing untuk Meningkatkan Kemampuan Berpikir Kritis dan Prestasi Belajar pada Materi Hasil Kali Kelarutan Kelas XI SMA Negeri 2 Sukoharjo Tahun Pelajaran 2013/2014. Dalam penelitian ini menggunakan metode Penelitian Tindakan Kelas (PTK), siswa melakukan diskusi kelompok, anggota kelompok sudah aktif dan saling kerja sama dalam memecahkan soal dalam diskus dan mempresentasikannya di depan kelas.

Artikel Peningkatan Kemampuan Berpikir Kritis dan Prestasi Belajar Matematika Melalui Model Pembelajaran Kooperatif Tipe NHT. Dalam penelitian ini menggunakan metode Penelitian Tindakan Kelas (PTK) dengan pendekatan kualitatif dan kuantitatif. Saat diterapkan model ini siswa mampu memberi jawaban dengan teori-teori yang sudah ada, mampu membuat kesimpulan materi, mengidentifikasikan dan menjelaskan definisi, membuat strategi dan taktik dalam menyelesaikan permasalahan yang diberikan oleh guru.

Artikel Penerapan Metode Pembelajaran Kooperatif Numberred Heads Togather untuk meningkatkan hasil belajar dan berpikir Kritis Siwa pada Mata Pelajaran IPS SD. Dalam penelitian ini menggunakan metode penelitian tindakan kelas. Kondisi kelas saat pembelajaran berjalan kondusif dan siswa mampu berpikir kritis, hal itu dapat dilihat dari respon siswa aktif bertanya ketika tidak 
paham mengenai materi yang diajarkan, dalam diskusi kelompok siswa saling bertukar pikiran dan mempunyai tanggung jawab kepada diri sendiri dan kelompoknya.

Artikel Penerapan Model Pembelajaran Numbered Heads Togather (NHT) untuk Meningkatkan Kemampuan Berpikir Kritis PKn Siswa Kelas VIII B8. Dalam penelitian ini menggunakan metode Penelitian Tindakan Kelas (PTK), kemampuan berpikir kritis siswa meningkat setelah menerapkan model Numbered Heads Togather (NHT). Hal ini disebabkan/Setiap siswa saling bekerjasama dengan berpikir kritis siswa. Hal ini dapat dilihat dari rata-rata peningkatan kemampuan berpikir kritis siswa yang menggunakan model Numbered Heads Togather (NHT) sebesar $51,6 \%$. Berdasarkan hasil analisis tersebut menunjukan bahwa model Numbered Heads Togather (NHT) mampu meningkatkan kemampuan berpikir kritis siswa. Selain meningkatkan berpikir kritis siswa model Numbered Head together juga dapat membuat siswa menjadi lebih aktif saling berdiskusi untuk memcahkan permasalahan dan memahami materi, Setiap siswa juga kelompoknya untuk menyelesaikan mempunyai tanggung jawab sendiri permasalahan. Siswa bertanggung jawab atas belajarnya secara atas tugas yang diberikan oleh guru.

individu, serta dapat meningkatkan keaktifan siswa dalam menemukan Kesimpulan dan Saran informasi untuk menjawab Kesimpulan permasalahan yang diberikan oleh guru.

Pembahasan hasil penelitian berdasarkan data pada Tabel 1 terlihat, bahwa penggunaan model Numbered Heads Togather (NHT) dapat meningkatkan kemampuan
Berdasarkan data hasil penelitian yang dilakukan secara studi literature, dapat disimpulkan bahwa penerapan model Numberred Heads Together (NHT) sudah banyak dilakukan oleh peneliti, model ini dapat meningkatkan kemampuan berpikir kritis siswa. Setelah melakukan analisis terhadap sepuluh artikel diatas dapat 
disimpulkan bahwa model kemampuan berpikir kritis siswa, Numberred Heads Together (NHT) dapat meningkatkan kemampuan berpikir kritis siswa dengan rata-rata $51,6 \%$. dengan nilai presentase terendah adalah $6 \%$ dan tertinggi mencapai $133 \%$.

bagi peneliti yang akan melakukan penelitian dengan model pembelajaran Numbered Head Together (NHT) untuk meningkatakan kemampuan berpikir kritis hasil dari penelelitian ini bisa dijadikan referensi serta diharapkan

Saran

Peneliti memberikan saran sebagai berikut: bagi guru diharapkan dalam pembelajaran dapat menggunakan model pembelajaran Numbered Heads Together (NHT) karena dapat

\section{Daftar Pustaka}

\section{Jurnal Pendidikan Kimia (JPK), 57-64.}

Achmad, A. A. (2018). Peningkatan

Kemampuan Berfikir Kritis Siswa Menggunakan Model Pembelajaran Kooperatif Tipe Numbered Head Togather Berbasis Problem Solving . Jurnal Pendidikan Surya Edukasi (JPSE), 1-11.

Andriyani, D., Susilowati, E., \& Mulyani, B. (2015).

Penerapan Model Numbered Head Togather (NHT)

Dilengkapi Catatan Terbimbing untuk Meningkatkan Kemampuan Berpikir Kritis dan Prestasi Belajar pada Materi Hasil Kali Kelarutan Kelas XI SMA Negeri 2 Sukoharjo Tahun Pelajaran 2013/2014.
Bano, N. D., Supu, A., \& Lantik, V. (2019). Penerapan Model Numbered Heads Togather dan Group Investigation. Edufisika: Jurnal Pendidikan Fisika, 56-64.

Fathurrohman, M. (2017). ModelModel Pembelajaran Inovatif. Jogjakarta: Ar-Ruzz Meda.

Fadliyani. (2016). Perbedaan Kemampuan Berpikir Kritis dan Kemampuan Berpikir Kreatif Matematika Siswa dengan Menggunakan Model Pembelajaran Konstektual Learning Tipe Numbered Heads Together pada Kelas V 
Negeri 104607 Sei Rotan. Jurnal Bina Gogik, 15-24.

Febrianti, F. A. (2019). Implementasi Model Pembelajaran Kooperatif Tipe Numbered Head Together (NHT) Dalam Meningkatkan Kemampuan Berpikir Kritis Siswa Pada Pembelajaran IPS. Journal Civics and Social Studies, 4252.

Hidayah, N., \& Anisa, W. (2019). Peningkatan Motivasi Belajar dan Kemampuan Berpikir Kritis Peserta Didik Menggunakan Model Think Pair Share Berbantuan Alat Peraga Bahan Bekas. ArRiayah: Jurnal Pendidikan Dasar, 165-178.

Khairani , Amry, Z., \& Harahap, R. (2018). Upaya Meningkatkan Kemampuan Berpikir Kritis Siswa Kelas X Melalui Pembelajaran Kooperatif Tipe Numbered Head Together. Jurnal Eksakata Pendidikan (JEP), 85-92.

Khasanah, F., \& Supriyono. (2016). Peningkatan Kemampuan Berpikir Kritis dan Prestasi Belajar Matematika Melalui Model Pembelajaran Kooperatif Tipe NHT. EKUIVALEN Pendidikan Matematika, 99-104.

Kristin, F. (2016). Analisis Model Pembelajaran Discovery Learning dalam Meningkatkan Hasil Belajar siswa SD. Journal
Pendidikan Dasar PerKhasa, 90-98.

Lismaya, L. (2019). Berpikir Kritis \& PBL (Problem Based Learning). Suarabaya: Media Sahabat Cendikia.

Machfud, H. (2018). Pnenrapan Model Pembelajaran Kooperatif Tipe Numberred Head Togather (NHT) untuk Meningkatkan Respons, Aktivitas, dan Hasil Belajar Siswa. Al-Khwarizmi: Jurnal Pendidikan Ilmu Matematika dan Ilmu Pengetahuan Alam, 105-120.

Novitasari, Alfi. (2015). Upaya Meningkatkan Kemampuan Berpikir Kritis Siswa Melalui Model Pembajaran Kooperatif Tipe Numbered Heads Togather (NHT) pada Siswa Kelas VIID SMP Negeri 11 Yogyakarta. Repository Universitas PGRI Yogyakarta. Diambil tanggal 21 Maret 2020. Dari http://repository.upy.ac.id/30 4/1/ARTIKEL.pdf
Permana, E. P. (2016). Penerapan Metode Pembelajaran Kooperatif Numbered Head Togather (NHT) umtuk Meningkatkan Hasil Belajar dan Berpikir Kritis Siswa pada Mata Pelajaran IPS SD. JPDN Jurnal Pendidikan Dasar Nusantara, 49-58.

Putra, D. A. (2018). Pembelajaran Berbasis CTL dan Inkuiri Untuk Meningkatkan Kemampuan Berpikir Kritis 
Siswa. ELSE (Elementary School Education Journal), 55-67.

Sari, M., \& Admendri. (2020). Penelitian Kepustakaan (Library Research) dalam Penelitian Pendidikan IPA. NATURAL SCIENCE: Jurnal Penelitian Bidang IPA, 4153.

Shoimin, A. (2017). 68 Model Pembelajaran Inovatif dalam Kurikulum 2013. Yogyakarta: Ar-Ruzz Media.

Siswono, T. Y. (2018). Pembelajaran Matematika Berbasis Pengajuan dan
Pemecahan Masalah Fokus pada Berpikir Kritis dan Berpikir Kreatif. Bandung: PT Remaja Rosdakarya.

Sugiyono. (2018). Metode Penelitian Kuantitatif, Kualitatif, dan $R \& D$. Bandung: Alfabeta.

Wati, W., \& Fatimah, R. (2016). Effect Size Model Pembelajaran Kooperatif Tipe Numberred Heads Togather (NHT) Terhadap Kemampuan Berpikir Kritis Siswa pada Pembelajaran Fisika. Jurnal Ilmiah Pendidikan Fisika Al-BiRuNi, 213-222. 